\title{
Selective Preference of Antibody Mimetics over Antibody, as Binding Molecules, for Diagnostic and Therapeutic Applications in Cancer Therapy
}

\author{
Pankaj Garg $1, *$ (D) \\ 1 Department of Chemistry, GLA University, Mathura, 281406, India \\ * Correspondence: pankaj.garg@gla.ac.in;
}

Scopus Author ID 571962558738

Received: 16.10.2020; Revised: 10.11.2020; Accepted: 12.11.2020; Published: 14.11.2020

\begin{abstract}
Despite wider use of monoclonal and polyclonal antibodies as therapeutic and diagnostic detection agents for different types of cancers, their limitations for biomedical applications have forced scientists to design alternate next-generation molecular binding reagents, the so-called antibody mimetics. The ultimate aim to produce antibody mimetics is to out-perform the intrinsic limitations of antibodies related to their binding affinities, tumor penetration, temperature, and $\mathrm{pH}$ stability. The current review highlights the advanced characteristics and constructional modification of alternate antibody mimetics, compared to animal source generated antibodies and their improved bioanalytical chemistry; especially in cancer treatment as a diagnostic and therapeutic tool.
\end{abstract}

Keywords: Antibody mimetic; Monoclonal antibodies (MoAbs); Protein scaffold engineering; Molecular Imaging; cancer therapy.

(C) 2020 by the authors. This article is an open-access article distributed under the terms and conditions of the Creative Commons Attribution (CC BY) license (https://creativecommons.org/licenses/by/4.0/).

\section{Introduction}

Antibodies, especially monoclonal antibodies, have been identified as effective tools both for therapeutic and diagnostic applications, especially in cancer therapy, on account of their high stability and specific affinity. Antibodies are Y-shaped glycoproteins produced by the immune system to counteract the effect of any foreign substance or antigen in the body. They can be polyclonal or monoclonal based on the types of immune cells from which they are produced. Polyclonal antibodies are produced by different types of immune cells having an affinity towards the same antigen, while monoclonal antibodies are produced from identical types of immune cells; that are the clones of a parent cell having an affinity for the same antigen and a particular epitope. The primary function of antibodies is to bind and neutralize a particular region of an antigen that is usually a harmful pathogen. The molecular forces responsible for this antigen-antibody interaction are mainly the electrostatic force, hydrogen bond, hydrophobic interaction, and van der Waal's force; their relative affinity depends on antigen structure and its composition [1-4].

Antibodies are considered the most successful and widespread affinity proteins for various life science applications due to their high specificity for any given target. However, the intrinsic limitations related to their molecular properties have some serious concerns relating to its crossreactivity while interacting with two or more antigens with similar chemical or molecular composition. Further, a relatively large size of antibody limits its use in the system where the recognition molecule is genetically or chemically modified or when incorporated with any 
biomaterial or in drug-delivery systems. . Another challenge relating to the use of antibodies is its thermal stability in extreme environmental conditions, which limits its use in remote locations and in countries where the facility of continuous power supply and refrigeration is not feasible All these shortcomings have limited the use of antibodies as universal targeting agents and led scientists to think of some other alternatives in the form of antibody mimetics to overcome these inherent limitations of antibody functions [5-6].

\section{Antibody mimetics: complementary antibody resembling molecules}

Antibody mimetics are defined as the molecules that can bind to antigen similarly to antibodies. However, the immune system does not generate them, and neither have they had any structure related resemblance to the antibodies. However, antibody mimetic offers distinct advantages over an antibody. It has a more straightforward structure with a single domain cysteine residue enabling its preparation in a soluble form even in prokaryotic cells. The advancement in its computational morphology (design), phage library construction, and selection system gifted it with exceptional selectivity and affinity. Moreover, its stability in extreme temperature and $\mathrm{pH}$ environment, highly ionic concentration, makes its use more desirable [7-8].

Antibody mimetic molecules are the unrelated protein scaffolds consisting of $\alpha$-helices, $\beta$ sheets, or random coils that can bind to specific targets and could be designed to incorporate new binding sites through protein engineering strategies. A variety of new techniques for its in-vitro generation have been advocated for developing a large number of non-antibody molecular repertories with high binding affinity and target specificity that can be considered with much improved molecular recognition properties and characterization such as small molecular size, enhanced stability, with high yield bacterial expression, and, more importantly, an option for multispecific targeting constructs [9-10]. The present review emphasizes the superiority of using antibody mimetic as an alternate tool to antibody, comparing results, and substantial scientific progress related to in-vivo imaging, therapy, and biotechnological approach [Table 1].

Table1. Comparison of antibody mimetics to antibodies.

\begin{tabular}{l|l|l} 
S.No. & \multicolumn{1}{|c}{ Antibody mimetics } & \multicolumn{1}{c}{ Antibodies } \\
\hline 1. & $\begin{array}{l}\text { Reproducible batch-to-batch preparation by recombinant and } \\
\text { synthetic means using a peptide synthesizer }\end{array}$ & $\begin{array}{l}\text { Lot-to-lot variability in polyclonal antibody } \\
\text { preparation }\end{array}$ \\
\hline 2. & $\begin{array}{l}\text { Expensive identification and engineering, inexpensive } \\
\text { production }\end{array}$ & $\begin{array}{l}\text { Costly production and upkeep of cell lines for } \\
\text { monoclonal antibody production }\end{array}$ \\
\hline 3. & Production in prokaryotes & $\begin{array}{l}\text { Require eukaryotic cell lines for production due to } \\
\text { posttranslational modifications }\end{array}$ \\
\hline 4. & Stable at extreme temperatures $\left(\sim 90^{\circ} \mathrm{C}\right)$ and other conditions & Limited thermal stability \\
\hline 5. & Small size & Large size \\
\hline 6. & Good tissue penetration & Low tissue penetration \\
\hline 7. & Simple post-isolation modification & Chemical modification is not trivial \\
\hline 8. & Long shelf lives (up to 2 years) & Relatively short shelf life $($ up to 6 months) \\
\hline 9. & Monovalent & Bivalent \\
\hline 10. & No activation of cell receptors & Activation of cell receptors \\
\hline 11. & Not immunogenic & Elicit immune response
\end{tabular}

\section{General protein engineering approach for the development of antibody mimetics}

Before focusing on the specific structures, analytical and biomedical applications of antibody mimetics and, more specifically, on their use as a diagnostic and therapeutic tool, it is important to have an idea of a general protein engineering approach to construct an antibody 
mimetic bio-molecule. The designing of a new antibody mimetic begins with the selection of an appropriate scaffold. The scaffold is a well defined three-dimensional protein structure that is open for mutations and insertions. In general, a scaffold is so selected that any modification in its primary structure can not hinder the flexibility in its secondary structure and its overall stability. The new molecule designed must be small, thermo-stable, and a single domain protein without any disulfide bond. After selecting the scaffold, the second step is the designing and construction of libraries using molecular biology protocols. Identification of a ligand-binding moiety for a newly generated antibody mimetic is a prerequisite. It is achieved by using x-ray crystallography and molecular modeling techniques [11-13].

After successfully designing and constructing the library, the translated scaffold protein molecule undergoes screening for mutants' isolation with desired properties. It can be assured that in a standard library with $10^{12}$ variants, a highly efficient screening method involving a phage display technique is required. The commonly used phage display system involves bacterial cell surface display, yeast display, m-RNA display, etc. Commercial kits for display methodologies are available for this purpose. After the evolution, construction, and selection processes, the identified variants with desired characteristics undergoes one or more selections to diversify the resulting library. Thus, using this methodology, protein scaffolds with high binding affinity can be obtained. The antibody mimetics genetically produced can further be modified based on their use for desired applications. Antibody mimetic can be modified through genetic and chemical conjugations and can be suited for therapeutic and imaging applications [Figure 1]. The only drawback of antibody mimetics is their labor-intensive and expensive production, limiting its wider use. The present review focuses on the bio-analytical antibody mimetics applications and their possible use as a diagnostic and therapeutic tool, especially for cancer research therapy [14$16]$.

\section{Different types of antibody mimetic molecules}

\subsection{Affibody molecules.}

Affibodies are one of the most important and widely used engineered protein scaffolds that originate from the $\beta$-domain present in the immunoglobulin binding region of staphylococcal protein A (SPA). The $\beta$-domain of SPA is a short and cysteine free peptide molecule, which consists of a series of 58 amino acids that are folded together to form a three $\alpha$-helical bundle like structure and can bind to the Fc portion of the IgG molecule. Further optimization of the affibody scaffold to improve its thermal and chemical stability was carried out by mutating the $\beta$-domain at its key position, and the resultant emerging variant obtained symbolized as Z-domain, holds a strong affinity for the Fc part of the antibody, and the weaker affinity for the Fab part of the antibody. Besides this, 13 more positions on helices-I and helices-II that forms the binding surface were also optimized to obtain high affinity and develop specific binding properties of affibody molecule with corresponding ligands. Thus the affibody molecule with this type of engineering modification acquires enhanced favorable properties of Z-domain with high thermal and chemical stability and rapid folding of protein molecule that can be advantageous in even wider varieties of applications and new molecular engineering technologies [17-19]. 


\subsection{Adnectin or monobodies.}

Adnectins are the synthetic binding proteins which are obtained from the extracellular domain of human fibronectin III protein (FN3). It consists of seven $\beta$-strands link together by six loops. The resultant structure of the $\beta$-domain obtained resembles in similarity to the variable region of antibodies, thus making adnectin a good candidate in the race of antibody mimetic. Adnectins, although having a simple structure as compared to antibodies, are similar to antibodies in specificity and binding affinity properties. This property of adnectin has been tested and evaluated against several ligands like vascular endothelial growth factor receptor-2 EGFR [20-22].

\subsection{Peptide aptamers and affimers.}

They are combinatorial protein structures with short peptide sequences and an inert and rigid scaffold structure. Both the N- \& C-termini of the binding peptide are fused. This double constrained structure is responsible for increasing binding affinity and specificity. It is important to emphasize that the rigid scaffold structure has an unreasonable potential to indulge in any further modification in its structure, which widens its employability for other analytical purposes. 'Avacta Life Sciences', developed a variety of peptide aptamers with much-improved performance and registered with a trade-mark name affimers for their products. These affimer products are being used for various analytical applications such as ELISA, microarray, affinity chromatogram, immuno-histochemistry, etc. Avacta has also designed and developed one affimer, specific to use for the Zika virus antigen that could enable the development of a diagnostic kit of the Zika virus test based on ELISA [23-25].

\subsection{DARPins.}

DARPin is commonly known as designed ankyrin repeat proteins. These are artificial scaffold proteins based on human ankyrin domain proteins responsible for modulating a more comprehensive range of protein interactions in different biological processes. They are composed of two to four repeated units linked by the N- \& C-termini, nearly for different folding to prevent their aggregation during protein expression. DARPins have been used in the bio-analytical and biomedical field due to their high binding affinity, rapid clearance ability, and well-executed tissue penetration. The lack of cysteine moiety in DARPin is responsible for increasing its solubility. The introduction of a different improved cysteine helps the conjugation of DARPin to different molecules like drugs, proteins, imaging reagents, and nano-materials. DARPins are reported to play an essential role in targeting molecules in delivering a payload to the target sites for diagnostic imaging and therapy purposes. Details of their imaging and therapy uses are highlighted in the application section [26-29].

\subsection{Affitins.}

Affitins are the variants of DNA binding proteins (Sac7d) that are engineered to develop specific binding affinities. Sac7d protein contains 66 amino acids that form an incomplete barrellike structure, composed of a double-stranded $\beta$-hairpin at $\mathrm{N}$-termini and a triple-stranded $\beta$-sheet at C-termini. Sac7d interacts with DNA through the three-stranded sheet. The binding affinity in affitin proteins developed through the randomization of 14 amino acids in the $\beta$-sheet. Affitins are highly resistant to a broad range of temperatures. They can be produced in large quantities using recombinant bacterial technologies [30-31]. 
4.6. Avimers.

These molecules are based on the A-domain of extracellular receptors. The A-domain contains 35 amino acids with three intramolecular disulfide bonds. These are highly resistant to temperature and are relatively smaller in comparison to other antibody mimetic scaffolds. Avimers are reported to show high binding affinity and specificity against different ligands and also high therapeutic efficacy. Their high binding specificity is frequently used for various analytical diagnostic and therapeutic purposes [32-34].

\subsection{Atrimers.}

These are the scaffold proteins derived from trimeric plasma protein called tetranectin, which is a family of C-type lectins with three identical units and five flexible loops that can mediate interaction with the target moieties. Several atrimer molecules have been developed as therapeutic biological analogs that can stimulate or block the specific ligands. Atrimers possess a lysine-rich unstructured region at its $\mathrm{N}$-terminus that is likely to be worthy for delivering different imaging agents and drug loading. Overall, atrimers are considered ideal imaging and binding molecules to target ligands for their biological activity [35-37].

\subsection{Anticalins.}

Anticalins are those groups of binding proteins with a conservative $\beta$-barrel structure present in the lipocalins. Lipocalins are proteins composed of eight antiparallels $\beta$-strands and a C-terminal $\alpha$-helix. The specific binding properties in anticalin can be developed through amino acids of its four hypervariable loops. Anticalin molecules have been used in various bio-analytical and clinical applications against a variety of targets. Antibody-anticalin fusion proteins are also used in pre-targeting applications as a tumor biomarker and target fluorescence dyes to tumor cells for in-vivo imaging in mice [38-40].

\section{Biomedical applications of antibody mimetics}

\subsection{Use of antibody mimetic in diagnostic and therapeutic applications.}

Antibody mimetics can be used to imaging different metabolic pathways, intracellular targets associated with cancer, and other diseases. Different research studies have shown that affibodies as compared to antibodies or its fragments are more potent tracers for HER-2 receptorrelated specific molecular imaging [41]. An affibody molecule ZHER2:342 with a chelate sequencing of maEE synthesize and labeled with technetium-99m was reported as an important tracer agent for clinical imaging and detection HER-2 overexpression in tumors [42]. Apart from this, the use of affibody has been successfully employed in the protein capture microarray technique due to its high specificity for the analysis of complex samples like a human serum or plasma [43]. Anticalins, a vital antibody mimetic when conjugated to a radioactive isotope element, can be an efficient candidate for featuring high contrast in-vivo diagnostic imaging. Anticalin (lipocalin) is also advocated as an important candidate for targeted immunotherapy of cancer and other infectious diseases. Anticalins are recognized as suitable candidates for treating digitalis intoxications and can be developed by fusing with ScFv. Anticalin, due to its small size, single polypeptide chain, and ease of preparation, can be considered as a potent candidate for 
therapeutic and diagnostic applications [44,45]. Adnectin, another alternate antibody mimetic, has been developed to address and treat rheumatoid arthritis, psoriatic arthritis without showing any significant side-effects that appeared during the use of a monoclonal antibody. Adnectin Ct-322 on binding with a receptor (VEGFR-2) vascular endothelial growth factor receptor-2, showed significant anti-tumor activity. The results obtained demonstrate its utility for the treatment of other diseases [46,47]. DARPins, another important antibody mimetic class, have been developed fused with anti-HER-2 receptor cells and CD-4 cells as anti-CD4 DARPins and anti-HER-2 DARPins; to block the entry of HIV into the cells [48].

\subsection{Use of antibody mimetics for detecting cancer biomarkers.}

The beneficial properties of alternate antibody reagents (antibody mimetics) like their specificity, ease of production, binding affinity, etc., have facilitated scientists to investigate their use as imaging agents for detecting cancer biomarkers. The importance of epidermal growth factor-2 oncogene (HER-2) in various oncogenic processes and its clinical detection in tissue biopsies have enlarged its use for biomarker development. In this series, DARPin, an important antibody mimetic molecule, has been identified in immunohistochemical applications for detecting HER-2 oncogene [49]. Similarly, an Anti-HER-2 affibody conjugate biomolecule has recently been developed and commercialized by 'Abacam' (Cambridge, U.K.) for its possible utility in immuno-histochemistry applications [50]. It is also worthwhile to mention here that certain HER2 specific nanobody reagents have been developed for their utility in tissue staining, and they are mainly used as in-vivo molecular imaging tools. Similarly, nanobodies have also found an application for other cancer biomarkers by staining cells in positive tumor regions [51-52].

Compared to an anti-ARTC2 antibody, a nanobody targeting an antigen ADPribosyltransferase (ARTC2.2) results in the homogeneous staining of positive xenograft cells, and this may likely be due to larger antibody size with less efficient tumor penetration [53]. In the same line, affimers, an important type of non-antibody binding protein molecules, have been detected to target the (VEGFR2) receptors, an important protein in the blood vessel formation in tumors. A similar staining pattern was observed with affimer molecule, much greater sensitivity reported than the anti-VEGR2 antibody. The greater sensitivity of affimer attributes to its smaller size with a much-improved ability to penetrate tissues compared to antibody. However, in the case of affimer molecule targeting Tenascin C (TNC); the sensitivity of staining tissues was reported to be slightly reduced, but these do not underestimate the utility of affimer as an important biomolecule for the detection of tumor biomarkers [54].

\subsection{Use of antibody mimetics as binding reagents for in-vivo tumor imaging.}

The ability of alternative non-antibody molecules or antibody mimetics, as binding reagents for in-vivo imaging of tumors, is an important tool in cancer diagnosis [55, 56]. With much smaller size and without the presence of Fc moiety as in antibody, these reagents enable high tumor penetration and permitting prompt clearance from the background tissues, thereby enhancing the efficacy and sensitivity of visualizing tumor imaging. Many antibody mimetic molecules like nanobodies, anticalins, affibody, etc., have been developed as more specific detection tools. [Table 2]. These alternate non-antibody molecules have been recognized with their ability to target the extracellular epitope in prostate-specific detection antigen (PSMA) and preferred over approved monoclonal antibodies functionality [57, 58]. 
In an attempt to investigate the therapeutic potential of alternate non-antibody binding protein molecules (antibody mimetic), scientists and researchers have developed their utility for tumor detection and in treatments (theranostics) [59]. Earlier radiolabeled antibodies were considered to be an ideal candidate for their use in radioimmunotherapy (RIT). At present, the FDA approved thirteen monoclonal antibodies for their possible use in RIT, and most of them have been used for targeting carcinomas. Monoclonal antibodies for targeting cancers are usually recommended. However, they are less successful due to its slow permeation rate to the target site. There is an urgent need for some smaller binding reagents with much-improved targeting properties [60]. The use of nanobodies conjugated to radio-lanthanides like lutetium-177 is therefore recommended for carrying out a dual function of both the detection and therapy of growth factor receptors expressing cancers [61]. The elementary data obtained for the use of antibodies reports the surrounding renal accumulation of antibodies in the non-specific organs like the liver, kidney, spleen, etc. Affibody is another reagent suggested to overcome this non-specific reticuloendothelial system (RES) uptake and can be a useful biomolecule for their possible use in pre-targeting strategies, where binding reagents are targeted initially to the tumor localization before the administration of the actual radioactivity [62, 63].

Table 2. Selected antibody mimetics \& their possible use in different imaging and targeting technologies.

\begin{tabular}{|c|c|c|c|c|}
\hline S. No. & Binding-Reagent & Target & Tumor-associated & References \\
\hline 1. & Affibody & $\begin{array}{l}\text { EGFR; for radiotherapy of HER-2- } \\
\text { Lu-177; CD- } 28 \text { profuse ligand } \\
\text { imaging; PET }{ }^{68} \mathrm{Ga},{ }^{64} \mathrm{Cu} \text {, etc. }\end{array}$ & $\begin{array}{l}\text { Colon, breast, ovarian. } \\
\text { Epidermoid and Prostrate, } \\
\text { Cervical. }\end{array}$ & Ref: 41,42 \\
\hline 2. & Anticalins & $\begin{array}{l}\text { HGFR, VEGF-A, PSMA, } \\
\text { autoimmunity, IL-17/IL-23, } \\
\text { laboratory \& clinical diagnostic tool. }\end{array}$ & Multiple tumors & Ref: 38,39 \\
\hline 3. & DARPins & $\begin{array}{l}\text { AMD, DME (VEGF-A), } \\
\text { Cardiovascular diseases, } \\
\text { Opthalmology, and CNS disorders. }\end{array}$ & Colon, breast \& ovarian. & Ref: 27,28 \\
\hline 4. & $\begin{array}{l}\text { AdNectin/ } \\
\text { Monobodies }\end{array}$ & $\begin{array}{l}\text { Antiangiogenesis in cancer, VEGF, } \\
\text { VEGF-R, rheumatoid arthritis, } \\
\text { psoriasis, etc. }\end{array}$ & Lungs, Breast \& Colon & Ref: 47,48 \\
\hline 5. & Affimer & $\begin{array}{l}\text { TNC, Zika virus antigen, micro- } \\
\text { array, affinity chromatography. }\end{array}$ & Multiple tumors & Ref: 54 \\
\hline 6. & Nanobody & EGFR, HER-2, HGF, MMR & $\begin{array}{l}\text { Epidermoid, Prostrate, } \\
\text { breast, ovarian, mammary } \\
\text { adenocarcinoma. }\end{array}$ & Ref: 51,52 \\
\hline 7. & Atrimers / Avimers & $\begin{array}{l}\text { Ligands, IL-23, Anaphore, } \\
\text { ATX3105, Tetravectin, Lipocalin, } \\
\text { etc. }\end{array}$ & $\begin{array}{l}\text { Cytotoxic T-cells, Auto- } \\
\text { immune cancer, breast, } \\
\text { colon, etc. }\end{array}$ & Ref: 36,37 \\
\hline
\end{tabular}

\section{Future prospectives \& challenges}

The bio-molecular recognition properties of antibodies and the inherent selectivity towards different specific or non-specific antigens endows them with ideal characteristics for use as suitable candidates in different biological technologies. However, because of their large size and complex structures, antibodies are susceptible to instability at extreme conditions of temperature and $\mathrm{pH}$, limiting their ability to penetrate inside the tissues. Therefore, the search for other alternative biomolecules is needed to overcome the shortcomings of antibodies effectively. This has led to the design of antibody mimetics. Antibody mimetics offer distinct advantages over antibodies due to their more straightforward structure and advancement in computational designing, library construction, and selection with high selective and binding affinity. Moreover, 
strategies employed to improve its properties like stability, binding affinity, etc.; under extreme conditions have also attracted the attention of the scientific community [64].

Although an antibody mimetic over antibody is preferred, certain factors limit the frequent employability of using antibody mimetics. The designing and modification of its protein scaffolds to introduce high binding affinity and selectivity characteristics translate into a high development cost. As such, it is difficult to afford to invest in high $\mathrm{R} \& \mathrm{D}$ expenditure for its further development and is restricted only in the hands of big Pharma and biotech giants. However, the recovery of its research and development costs can be compensated for their utility as therapeutic agents in targeted immunotherapy. Despite the proven advantages of antibody mimetics, certain issues are associated, such as immunogenicity, short plasma half-life, and lack of effectors function. The antibody mimetics have shorter half-lives as they lack the Fc region and, as such, have lower molecular weights compared to antibodies. Due to the Fc region's absence, they cannot mediate antibody-dependent phagocyte effect. They cannot bind to the Fc receptors found on the surface of cells [65].

Several technologies like PEGylation, PASylation, etc. have been suggested to increase antibody mimetics' molecular size and its plasma half-life. Alternatively, antibody mimetic efficacy can also be increased by extending their half-life by binding to a small ABD protein of 5KDa. Thus, antibody mimetics' biological activity can be increased many times despite their reduced size and increased affinity. However, the effects of antibody mimetics in treating diseases other than solid tumors and auto-immune diseases still need further assessment.

\section{Conclusions}

For so many years of antibodies dominating as selective binding reagents for various molecular recognition techniques, the paradigm has now shifted towards using alternative nonantibody binding molecules, so-called antibody mimetics, with several advantages over traditional antibodies. These non-antibody scaffolds offer high stability and binding affinity, having a smaller size that enables them to penetrate well inside the target tissues and access the epitope more readily than antibodies for targeted therapy and imaging of tumors. We anticipate that the use of antibody mimetics will become wider concerning biological and medical imaging applications.

\section{Funding}

This research received no external funding.

\section{Acknowledgments}

I want to thank my esteemed teacher and guide Prof. D.K. Hazra, Emeritus Scientist, Department of Nuclear Medicine, S.N.Medical College, Agra, India, for his kind support and help carry out this work. The support of all the staff members of the Nuclear Medicine Department, S.N.Medical College, Agra, \& Department of Chemistry, GLA University, Mathura, India, is sincerely acknowledged.

\section{Conflicts of Interest}

The authors declare no conflict of interest. 


\section{References}

1. Lu, R.-M.; Hwang, Y.-C.; Liu, I.J.; Lee, C.-C.; Tsai, H.-Z.; Li, H.-J.; Wu, H.-C. Development of therapeutic antibodies for the treatment of diseases. J. Biomed. Sci. 2020, 27, 1, https://doi.org/10.1186/s12929-019-0592-Z

2. Yamada, K.; Ito, Y. Recent Chemical Approaches for Site-Specific Conjugation of Native Antibodies: Technologies toward Next-Generation Antibody-Drug Conjugates. ChemBioChem 2019, 20, 2729-2737, https://doi.org/10.1002/cbic.201900178.

3. Iwasaki, A.; Yang, Y. The potential danger of suboptimal antibody responses in COVID-19. Nature Reviews Immunology 2020, 20, 339-341, https://doi.org/10.1038/s41577-020-0321-6.

4. Deckert, P.M. Current Constructs and Targets in Clinical Development for Antibody- Based Cancer Therapy. Curr. Drug Targets 2009, 10, 158-175,https://doi.org/10.2174/138945009787354502.

5. Yu, X.; Yang Y. P.; Dikici, E.; Deo, S. K.; Daunert, S. Beyond antibodies as binding partners: The role of antibody mimetics in bioanalysis. Annu. Rev. Anal. Chem. 2017, 10, 293-320, https://doi10.10.1146/annurevanchem-061516-045205.

6. Weidle, U.H.; Auer, J.; Brinkmann, U.; Georges, G.; Tiefenthaler, G. The emerging role of new protein scaffoldbased agents for treatment of cancer. Cancer Genomics-Proteomics 2013, 10, 155-168.

7. Löfblom, J.; Frejd, F.Y.; Ståhl, S. Non-immunoglobulin based protein scaffolds. Curr. Opin. Biotechnol. 2011, 22, 843-848, https://doi.org/10.1016/j.copbio.2011.06.002.

8. Š́krlec, K.; Štrukelj, B.; Berlec, A. Non-immunoglobulin scaffolds: a focus on their targets. Trends Biotechnol. 2015, 33, 408-418, https://doi.org/10.1016/j.tibtech.2015.03.012.

9. Binz, H.K.; Amstutz, P.; Plückthun, A. Engineering novel binding proteins from nonimmunoglobulin domains. Nat. Biotechnol. 2005, 23, 1257-1268,https://doi.org/10.1038/nbt1127.

10. Kadonosono, T.; Yimchuen, W.; Ota, Y.; See, K.; Furuta, T.; Shiozawa, T.; Kitazawa, M.; Goto, Y.; Patil, A.; Kuchimaru, T.; Kizaka-Kondoh, S. Design Strategy to Create Antibody Mimetics Harbouring Immobilised Complementarity Determining Region Peptides for Practical Use. Sci. Rep. 2020, 10, 891, https://doi.org/10.1038/s41598-020-57713-4.

11. Kuhn, P.; Fühner, V.; Unkauf, T.; Moreira, G.M.S.G.; Frenzel, A.; Miethe, S.; Hust, M. Recombinant antibodies for diagnostics and therapy against pathogens and toxins generated by phage display. PROTEOMICS-Clinical Applications 2016, 10, 922-948.

12. Béhar, G.; Kambarev, S.; Jazat, J.; Mouratou, B.; Pecorari, F. Whole-Bacterium Ribosome Display Selection for Isolation of Antibacterial Affitins. In Peptide and Protein Engineering, Springer: 2020; 153-171, https://doi.org/10.1007/978-1-0716-0720-6_9.

13. Kim, J.H.; Kim, S.C.; Kline, M.A.; Grzincic, E.M.; Tresca, B.W.; Cardiel, J.; Karbaschi, M.; Dehigaspitiya, D.C.; Chen, Y.; Udumula, V.; Jian, T.; Murray, D.J.; Yun, L.; Connolly, M.D.; Liu, J.; Ren, G.; Chen, C.-L.; Kirshenbaum, K.; Abate, A.R.; Zuckermann, R.N. Discovery of Stable and Selective Antibody Mimetics from Combinatorial Libraries of Polyvalent, Loop-Functionalized Peptoid Nanosheets. ACS Nano 2020, 14, 185-195, https://doi.org/10.1021/acsnano9b07498.

14. Simeon, R.; Chen, Z. In vitro-engineered non-antibody protein therapeutics. Protein \& Cell 2018, 9, 3-14, https://doi.org/10.1007/s13238-017-0386-6.

15. Garg, P. Filamentous bacteriophage: a prospective platform for targeting drugs in phage-mediated cancer therapy. J. Cancer Res. Ther. 2019, 15, 1, https://doi.org/10.4103/jcrt.JCRT_218_18.

16. Falck, G.; Müller, K.M. Enzyme-based labeling strategies for antibody-drug conjugates and antibody mimetics. Antibodies 2018, 7, 4, https://doi.org/10.3390/antib7010004.

17. Tolmachev, V.; Orlova, A. Affibody Molecules as Targeting Vectors for PET Imaging. Cancers (Basel) 2020, 12, 651, https://doi.org/10.3390/cancers12030651.

18. Feldwisch, J.; Tolmachev, V.; Lendel, C.; Herne, N.; Sjöberg, A.; Larsson, B.; Rosik, D.; Lindqvist, E.; Fant, G.; Höidén-Guthenberg, I.; Galli, J.; Jonasson, P.; Abrahmsén, L. Design of an Optimized Scaffold for Affibody Molecules. J. Mol. Biol. 2010, 398, 232-247, https://doi.org/10.1016/j.jmb.2010.03.002.

19. Vazquez-Lombardi, R.; Phan, T.G.; Zimmermann, C.; Lowe, D.; Jermutus, L.; Christ, D. Challenges and opportunities for non-antibody scaffold drugs. Drug Discov. Today 2015, 20, 1271-1283, https://doi.org/10.1016/j.drudis.2015.09.004.

20. Hantschel, O.; Biancalana, M.; Koide, S. Monobodies as enabling tools for structural and mechanistic biology. Curr. Opin. Struct. Biol. 2020, 60, 167-174, https://doi.org/10.1016/j.sbi.2020.01.015.

21. Bloom, L.; Calabro, V. FN3: a new protein scaffold reaches the clinic. Drug Discov. Today 2009, 14, 949-955, https://doi.org/10.1016/j.drudis.2009.06.007.

22. Park, S.-H.; Park, S.; Kim, D.-Y.; Pyo, A.; Kimura, R.H.; Sathirachinda, A.; Choy, H.E.; Min, J.-J.; Gambhir, S.S.; Hong, Y. Isolation and characterization of a monobody with a fibronectin domain III scaffold that specifically binds EphA2. PLoS One 2015, 10, e0132976, https://doi.org/10.1371/journal.pone.0132976.

23. Chen, Z.; Wu, Q.; Chen, J.; Ni, X.; Dai, J. A DNA Aptamer Based Method for Detection of SARS-CoV-2 Nucleocapsid Protein. Virol. Sin. 2020, 35, 351-354, https://doi.org/10.1007/s12250-020-00236-z.

24. Tans, R.; van Rijswijck, D.M.H.; Davidson, A.; Hannam, R.; Ricketts, B.; Tack, C.J.; Wessels, H.J.C.T.; Gloerich, J.; van Gool, A.J. Affimers as an alternative to antibodies for protein biomarker enrichment. Protein Expression Purif. 2020, 174, 105677, https://doi.org/10.1016/j.pep.2020.105677. 
25. Liu, K.; Xie, F.; Zhao, T.; Zhang, R.; Gao, A.; Chen, Y.; Li, H.; Zhang, S.; Xiao, Z.; Li, J. Targeting SOX2 Protein with Peptide Aptamers for Therapeutic Gains against Esophageal Squamous Cell Carcinoma. Mol. Ther. 2020, 28, 901-913, https://doi.org/10.1016/j.ymthe.2020.01.012.

26. Vorobyeva, A.; Schulga, A.; Konovalova, E.; Güler, R.; Mitran, B.; Garousi, J.; Rinne, S.; Löfblom, J.; Orlova, A.; Deyev, S. Comparison of tumor-targeting properties of directly and indirectly radioiodinated designed ankyrin repeat protein (DARPin) G3 variants for molecular imaging of HER2. Int. J. Oncol. 2019, 54, 12091220, https://doi.org/10.3892/ijo.2019.4712.

27. Moody, P.; Chudasama, V.; Nathani, R.I.; Maruani, A.; Martin, S.; Smith, M.E.B.; Caddick, S. A rapid, siteselective and efficient route to the dual modification of DARPins. Chem. Commun. 2014, 50, 4898-4900, https://doi.org/10.1039/C4CC00053F.

28. Goldstein, R.; Sosabowski, J.; Livanos, M.; Leyton, J.; Vigor, K.; Bhavsar, G.; Nagy-Davidescu, G.; Rashid, M.; Miranda, E.; Yeung, J.; Tolner, B.; Plückthun, A.; Mather, S.; Meyer, T.; Chester, K. Development of the designed ankyrin repeat protein (DARPin) G3 for HER2 molecular imaging. Eur. J. Nucl. Med. Mol. Imag. 2015, 42, 288-301,https://doi.org/10.1007/s00259-014-2940-2.

29. Stumpp, M.T.; Dawson, K.M.; Binz, H.K. Beyond Antibodies: The DARPin® Drug Platform. Biodrugs 2020, 34, 423-433, https://doi.org/10.1007/s40259-020-00429-8.

30. Béhar, G.; Renodon-Cornière, A.; Mouratou, B.; Pecorari, F. Affitins as robust tailored reagents for affinity chromatography purification of antibodies and non-immunoglobulin proteins. J. Chromatogr. 2016, 1441, 4451, https://doi.org/10.1016/j.chroma.2016.02.068.

31. Krehenbrink, M.; Chami, M.; Guilvout, I.; Alzari, P.M.; Pécorari, F.; Pugsley, A.P. Artificial binding proteins (Affitins) as probes for conformational changes in secretin PulD. J. Mol. Biol. 2008, 383, 1058-1068, https://doi.org/10.1016/j.jmb.2008.09.016.

32. Huang, W.; Dolmer, K.; Gettins, P.G.W. NMR solution structure of complement-like repeat CR8 from the low density lipoprotein receptor-related protein. J. Biol. Chem. 1999, 274, 14130-14136, https://doi.org/10.1074/jbc.274.20.14130.

33. North, C.L.; Blacklow, S.C. Structural Independence of Ligand-Binding Modules Five and Six of the LDL Receptor. Biochemistry 1999, 38, 3926-3935, https://doi.org/10.1021/bi9821622.

34. Silverman, J.; Lu, Q.; Bakker, A.; To, W.; Duguay, A.; Alba, B.M.; Smith, R.; Rivas, A.; Li, P.; Le, H.; Whitehorn, E.; Moore, K.W.; Swimmer, C.; Perlroth, V.; Vogt, M.; Kolkman, J.; Stemmer, W.P.C. Multivalent avimer proteins evolved by exon shuffling of a family of human receptor domains. Nat. Biotechnol. 2005, 23, 1556-1561, https://doi.org/10.1038/nbt1166.

35. Chandler, P.G.; Buckle, A.M. Development and Differentiation in Monobodies Based on the Fibronectin Type 3 Domain. Cells 2020, 9, 610, https://doi.org/10.3390/cells9030610.

36. Zelensky, A.N.; Gready, J.E. The C-type lectin-like domain superfamily. The FEBS Journal 2005, 272, 61796217, https://doi.org/10.1111/j.1742-4658.2005.05031.x.

37. Byla, P.; Andersen, M.H.; Holtet, T.L.; Jacobsen, H.; Munch, M.; Gad, H.H.; Thøgersen, H.C.; Hartmann, R. Selection of a Novel and Highly Specific Tumor Necrosis Factor $\alpha(\mathrm{TNF} \alpha)$ antagonist insight from the crystal structure of the antagonist-tnf $\alpha$ complex. J. Biol. Chem. 2010, 285, 12096-12100, https://doi.org/10.1074/jbc.M109.063305.

38. Skerra, A. Alternative binding proteins: Anticalins - harnessing the structural plasticity of the lipocalin ligand pocket to engineer novel binding activities. The FEBS Journal 2008, 275, 2677-2683, https://doi.org/10.1111/j.1742-4658.2008.06439.x.

39. Schiefner, A.; Skerra, A. The Menagerie of Human Lipocalins: A Natural Protein Scaffold for Molecular Recognition of Physiological Compounds. Acc. Chem. Res. 2015, 48, 976-985, https://doi.org/10.1021/ar5003973.

40. Garg, P.; Hazra, D.K. Conjugation of antibodies with radiogold nanoparticles, as an effector targeting agents in radiobioconjugate cancer therapy: Optimized labeling and biodistribution results. Indian journal of nuclear medicine: IJNM: the official journal of the Society of Nuclear Medicine, India 2017, 32, 296, https://doi.org/10.4103/ijnm.IJNM_80_17.

41. Löfblom, J.; Feldwisch, J.; Tolmachev, V.; Carlsson, J.; Ståhl, S.; Frejd, F.Y. Affibody molecules: Engineered proteins for therapeutic, diagnostic and biotechnological applications. FEBS Lett. 2010, 584, 2670-2680, https://doi.org/10.1016/j.febslet.2010.04.014.

42. Tran, T.; Engfeldt, T.; Orlova, A.; Sandström, M.; Feldwisch, J.; Abrahmsén, L.; Wennborg, A.; Tolmachev, V.; Karlström, A.E. 99mTc-maEEE-ZHER2:342, an Affibody Molecule-Based Tracer for the Detection of HER2 Expression in Malignant Tumors. Bioconj. Chem. 2007, 18, 1956-1964, https://doi.org/10.1021/bc7002617.

43. Xu, Y.; Wang, L.; Pan, D.; Yan, J.; Wang, X.; Yang, R.; Li, M.; Liu, Y.; Yang, M. Synthesis of a novel 89Zrlabeled HER2 affibody and its application study in tumor PET imaging. EJNMMI Research 2020, 10, 58, https://doi.org/10.1186/s13550-020-00649-7.

44. Deuschle, F.-C.; Morath, V.; Schiefner, A.; Brandt, C.; Ballke, S.; Reder, S.; Steiger, K.; Schwaiger, M.; Weber, W.; Skerra, A. Development of a high affinity Anticalin directed against human CD98hc for theranostic applications. Theranostics 2020, 10, 2172-2187, https://doi.org/10.7150/thno.38968.

45. Schönfeld, D.; Matschiner, G.; Chatwell, L.; Trentmann, S.; Gille, H.; Hülsmeyer, M.; Brown, N.; Kaye, P.M.; Schlehuber, S.; Hohlbaum, A.M.; Skerra, A. An engineered lipocalin specific for CTLA-4 reveals a combining 
site with structural and conformational features similar to antibodies. Proceedings of the National Academy of Sciences 2009, 106, 8198, https://doi.org/10.1073/pnas.0813399106.

46. Mamluk, R.; Carvajal, I.M.; Morse, B.A.; Wong, H.K.; Abramowitz, J.; Aslanian, S.; Lim, A.-C.; Gokemeijer, J.; Storek, M.J.; Lee, J.; Gosselin, M.; Wright, M.C.; Camphausen, R.T.; Wang, J.; Chen, Y.; Miller, K.; Sanders, K.; Short, S.; Sperinde, J.; Prasad, G.; Williams, S.; Kerbel, R.S.; Ebos, J.; Mutsaers, A.; Mendlein, J.D.; Harris, A.S.; Furfine, E.S. Anti-tumor effect of CT-322 as an Adnectin inhibitor of vascular endothelial growth factor receptor-2. MAbs 2010, 2, 199-208, https://doi.org/10.4161/mabs.2.2.11304.

47. Lipovšek, D. Adnectins: engineered target-binding protein therapeutics. Protein Engineering, Design and Selection 2011, 24, 3-9, https://doi.org/10.1093/protein/gzq097.

48. Schweizer, A.; Rusert, P.; Berlinger, L.; Ruprecht, C.R.; Mann, A.; Corthésy, S.; Turville, S.G.; Aravantinou, M.; Fischer, M.; Robbiani, M. CD4-specific designed ankyrin repeat proteins are novel potent HIV entry inhibitors with unique characteristics. PLoS Pathog. 2008, 4, e1000109, https://doi.org/10.1371/journal.ppat.1000109.

49. Liu, D. Cancer biomarkers for targeted therapy. Biomarker Research 2019, 7, 25, https://doi.org/10.1186/s40364-019-0178-7.

50. Vaneycken, I.; Govaert, J.; Vincke, C.; Caveliers, V.; Lahoutte, T.; De Baetselier, P.; Raes, G.; Bossuyt, A.; Muyldermans, S.; Devoogdt, N. In vitro analysis and in vivo tumor targeting of a humanized, grafted nanobody in mice using pinhole SPECT/micro-CT. J. Nucl. Med. 2010, 51, 1099-1106, https://doi.org/10.2967/jnumed.109.069823.

51. Vaneycken, I.; Devoogdt, N.; Van Gassen, N.; Vincke, C.; Xavier, C.; Wernery, U.; Muyldermans, S.; Lahoutte, T.; Caveliers, V. Preclinical screening of anti-HER2 nanobodies for molecular imaging of breast cancer. The FASEB Journal 2011, 25, 2433-2446, https://doi.org/10.1096/fj.10-180331.

52. Xavier, C.; Vaneycken, I.; D’huyvetter, M.; Heemskerk, J.; Keyaerts, M.; Vincke, C.; Devoogdt, N.; Muyldermans, S.; Lahoutte, T.; Caveliers, V. Synthesis, preclinical validation, dosimetry, and toxicity of 68GaNOTA-anti-HER2 Nanobodies for iPET imaging of HER2 receptor expression in cancer. J. Nucl. Med. 2013, 54, 776-784, https://doi.org/10.2967/jnumed.112111021.

53. Bannas, P.; Lenz, A.; Kunick, V.; Fumey, W.; Rissiek, B.; Schmid, J.; Haag, F.; Leingärtner, A.; Trepel, M.; Adam, G.; Koch-Nolte, F. Validation of Nanobody and Antibody Based In Vivo Tumor Xenograft NIRFimaging Experiments in Mice Using Ex Vivo Flow Cytometry and Microscopy. JoVE 2015, e52462, https://doi.org/10.3791/52462.

54. Tiede, C.; Bedford, R.; Heseltine, S.J.; Smith, G.; Wijetunga, I.; Ross, R.; AlQallaf, D.; Roberts, A.P.E.; Balls, A.; Curd, A. Affimer proteins are versatile and renewable affinity reagents. Elife 2017, 6, e24903, https://doi.org/10.7554/eLife.24903.

55. Yang, E.Y.; Shah, K. Nanobodies: Next Generation of Cancer Diagnostics and Therapeutics. Front. Oncol. 2020, 10, 1182, https://doi.org/10.3389/fonc.2020.01182.

56. Luo, H.; Hernandez, R.; Hong, H.; Graves, S.A.; Yang, Y.; England, C.G.; Theuer, C.P.; Nickles, R.J.; Cai, W. Noninvasive brain cancer imaging with a bispecific antibody fragment, generated via click chemistry. Proceedings of the National Academy of Sciences 2015, 112, 12806, https://doi.org/10.1016/j.coche.2013.08.

57. Bedford, R.; Tiede, C.; Hughes, R.; Curd, A.; Mc-Pherson, M. J.; Peckham, M.; Tomlinson, D. C. Alternative reagents to antibodies in imaging applications. Biophys. Rev. 2017, 9, 299-308, https://doi.org/10.1007/s12551017-0278-2.

58. Crook, Z.R.; Nairn, N.W.; Olson, J.M. Miniproteins as a Powerful Modality in Drug Development. Trends Biochem. Sci. 2020, 45, 332-346,https://doi.org/10.1016/j.tibs.2019.12.008.

59. Shilova, O.N.; Deyev, S.M. DARPins: Promising Scaffolds for Theranostics. Acta Naturae 2019, 11, 42-53, https://doi.org/10.32607/20758251-2019-11-4-42-53.

60. Rinne, S.S.; Leitao, C.D.; Mitran, B.; Bass, T.Z.; Andersson, K.G.; Tolmachev, V.; Ståhl, S.; Löfblom, J.; Orlova, A. Optimization of HER3 expression imaging using affibody molecules: Influence of chelator for labeling with indium-111. Sci. Rep. 2019, 9, 655, https://doi.org/10.1038/s41598-018-36827-w.

61. Vosjan, M.J.W.D.; Vercammen, J.; Kolkman, J.A.; Stigter-van Walsum, M.; Revets, H.; van Dongen, G.A.M.S. Nanobodies targeting the hepatocyte growth factor: potential new drugs for molecular cancer therapy. Mol. Cancer Ther. 2012, 11, 1017-1025, https://doi.org/10.1158/1535-7163.MCT-11-0891.

62. Hazra, D.K.; Garg, P. Pretargeting in radio bio-conjugate therapy: with reference to" rhenium, gold \& lutetium as candidate therapy isotopes". Indian J. Nucl. Med. 2007, 22, 1.

63. Barozzi, A.; Lavoie, R.A.; Day, K.N.; Prodromou, R.; Menegatti, S. Affibody-Binding Ligands. Int. J. Mol. Sci. 2020, 21, 3769, https://doi.org/10.3390/ijms21113769.

64. Hober, S.; Lindbo, S.; Nilvebrant, J. Bispecific applications of non-immunoglobulin scaffold binders. Methods 2019, 154, 143-152, https://doi.org/10.1016/j.ymeth.2018.09.010.

65. Chen, W.; Shen, B.; Sun, X. Analysis of progress and challenges of EGFR-targeted molecular imaging in cancer with a focus on affibody molecules. Mol. Imaging 2019, 18,https://doi.org/10.1177/1536012118823473. 